Article

\title{
Environmental Education in Environmental Engineering: Analysis of the Situation in Colombia and Latin America
}

\author{
Pedro Mauricio Acosta Castellanos ${ }^{1,2, *(\mathbb{C})}$, Araceli Queiruga-Dios ${ }^{3}{ }^{[}$, \\ Ascensión Hernández Encinas ${ }^{4}$ and Libia Cristina Acosta ${ }^{5}$ \\ 1 Faculty of Environmental Engineering, Universidad Santo Tomás, Tunja 150003, Colombia \\ 2 Doctoral School, Education in the Knowledge Society, Universidad de Salamanca, 37007 Salamanca, Spain \\ 3 Department of Applied Mathematics, School of Industrial Engineering, Universidad de Salamanca, Béjar, \\ 37700 Salamanca, Spain; queirugadios@usal.es \\ 4 Department of Applied Mathematics, Faculty of Sciences, Universidad de Salamanca, \\ 37008 Salamanca, Spain; ascen@usal.es \\ 5 Faculty of Administrative and Accounting Economics, Universidad Libre, Bogotá 111711, Colombia; \\ lcacostac@unal.edu.co \\ * Correspondence: pedro.acosta@usantoto.edu.co
}

Received: 28 July 2020; Accepted: 1 September 2020; Published: 4 September 2020

\begin{abstract}
Environmental education (EE) has become the only tool for environmental sustainability in training processes in Colombia, for basic cycles in primary and secondary, as well as university education. EE tends to transform human actions in nature, based on multidisciplinary knowledge that supports decision-making. Its goal is to generate a change in social behavior in order to achieve the recovery, conservation, and preservation of the environment. In Colombia, education for sustainable development (ESD) is embedded in EE. These educational models (EE and ESD) seek to achieve sustainable development goals (SDGs), which generally seek the economic and social well-being of nations, both for current and future generations. Environmental engineering is a relatively new degree course in Colombia and Latin America since it appeared in the mid-nineties, and it must involve EE within its curriculum. Students are trained in this trend. This research intends to demonstrate, through a curricular review of the environmental engineering curricula and also surveying students from this degree, the level of inclusion of EE in Latin America. Strengths are identified in the curricula, such as the strong presence of EE in disciplinary subjects and opportunities for improvement based on the needs of the students. The situation in South America is also included in this study.
\end{abstract}

Keywords: environmental education; education for sustainable development; curriculum improvement

\section{Introduction}

Currently, humanity faces changes that appear to be irreversible. These changes are the result of bad actions and social development, with little or no environmental responsibility, establishing a series of global challenges such as climate change and the degradation of natural resources [1].

These challenges also concern universities and their programs, so much so that broader definitions are found about the integration of the environment into these programs, Vidiella, defined the university as "a place where awareness must be created so that humans, through their activity, have promoted socioenvironmental changes in recent years; likewise, integrally train people so that they are capable of understanding society and intervening in it with the aim of improving it" [2]. Environmental education, as well as education for sustainable development, has become two currents within comprehensive 
training in higher education, with the goal of protecting natural resources for future generations using different concepts and paths.

EE has historically more weight than ESD. For this reason, countries like Colombia have decided to focus their educational policy towards EE, neglecting ESD [3,4]. However, it is assumed that due to the characteristics of university environments, where research and scientific advances are born or amplified, the novel characteristics of EDS should at least be addressed or evaluated [5].

Education for sustainable development is defined as "the process of equipping students with the knowledge, understanding, skills and necessary attributes to work and live in a way that safeguards environmental, social, and economic well-being, both in the present and for future generations" [6]. Moreover, ESD's aim is to develop a comprehensive transformation of educational systems to promote skills, knowledge, and values, and to equip people with the skills to make them able to cocreate a sustainable future [7]. ESD is based on the concept and model of sustainable development presented at the United Nations (UN) general assembly on 4 August 1987. The report entitled "Our common future", also known as the Brundtland report [8], was defined as "development that meets the needs of the present without compromising the ability of future generations to meet their own needs". Thereafter, all nations that had not achieved economic and social development have pointed to this model, which seeks a balance that inevitably involves the environment, since intergenerational equity is not possible without involving this factor [9]. More than 30 years have passed since this model was proposed, and some progress has been noticed, but it is difficult to reach an agreement about the route to achieving this type of development. To overcome these impasses, different strategies from the UN have been discussed; the last one is the formulation of a series of guidelines to achieve, called "sustainable development goals" [10].

In order to achieve the SDGs, it is necessary to do it through education [11,12]. This is why sustainability should be involved in the curricula and educational models, emerging as the concept of education for sustainable development [13].

Although there is no simple or consensual definition for EE, it can be classified as heterogeneous and diverse since it concerns basic primary education to higher education, regardless of the area of knowledge. EE provides a common, clear, and defined core, as it raises the need to promote a change in behavior in relation to the environment, apart from the approach or the didactic strategy that is used [7]. During a conference on environmental education, to give an answer to the complexity of the environment and its links with biological, physical, social, cultural, and socioeconomic factors was stated [14]. In the same way, it is usual to see EE emphasizing awareness and providing tools to acquire information on environmental sustainability, focusing on promoting ecological behaviors and critical thoughts about excessive consumption $[15,16]$. Information for smart decision-making in the face of the environment and how to protect it was also included in that conference $[17,18]$.

In universities, EE must guide students to know their environment, both in human actions and acts of nature, and how to generate an action strategy to protect the environment. To make this possible, it is necessary to teach students in a practical, theoretical, and innovative way, with actions and tools aimed at improving the environment [19]. In this sense, many of the universities face a great challenge since so few of them involve the environment within their functions. In Latin America, environmental education is still seen as something that only involves primary and secondary education [4], but not higher education, since it implies voluntary changes in restructuring the curricula of undergraduate and postgraduate programs. Therefore, this change would imply recognizing the importance of the environment in people's lives and in the development of societies in the educational system. Therefore, it would imply the use of EE in the curricula and in the universities themselves [20].

Based on what has been described, the importance of EE and ESD can be inferred, not only in the evolutionary process of universities and their programs but also in the development that nations need to achieve. In Colombia and Latin America, bachelor degrees are the first stage in higher education; they should promote these models since this stage in formal education gives shape to the future of people and, therefore, of societies [21]. 
Environmental engineering arose from the evolution of sanitary engineering and civil engineering; both engineering degrees addressed environmental issues in their curriculum. More specifically, sanitary engineering is the area related to environmental health, whose objective, broadly speaking, is to analyze the effects of using toxic elements in the environment on human health [22], and civil engineering is in charge of water resource issues [23]. The creation of environmental engineering in Latin America is very recent, and the first environmental degrees emerged in engineering programs in Colombia and much of Latin America during the nineties. The first degrees were sanitary and environmental engineering, but, over time, the word sanitary was removed from the name, since environmental issues had gained more relevance within the curricula and were somewhat overcome, at least in the countries with the greatest advances, problems associated with a lack of basic sanitation. However, the curricula or study plans continued to have their foothold mainly only in the technique that was very inclined to that health origin.

The training of environmental engineers has a very clear curricular core and areas of training, such as basic sciences, basic engineering, formative research, applied engineering, and ethics or humanism, which will depend on the approach of the university that offers the program. This is because the environmental engineer seeks the technique to solve environmental problems, that is to say, to decontaminate and not to stop the contaminating action; making an analogy with medicine, i.e., the objective is curative, but not preventive.

Environmental education has become a part of everyday life around the world, addressing environmental problems by changing the curricula in higher education. Likewise, to include courses, subjects, or programs, seems to be the most adequate proposal for EE [24,25]. However, it has been shown that the curricular change has not been carried out by many universities, and those that have carried it out have not had satisfactory results [26]. On the other hand, it has also been shown that teacher-student integration, in a collaborative way, is most effective in addressing environmental education in higher education programs [27]. It is generally considered that university students who study programs related to the environment have a better perspective on environmental problems, and it would be assumed that they have better training in environmental education; this is not always the case [28].

The objective of this research is to identify the presence of environmental education in the training of environmental engineers in Colombia; this will contribute to the knowledge of whether training is deficient or appropriate. To achieve this objective, a search was carried out on the environmental engineering programs that stand out for the quality accreditation granted by the Colombian Ministry of Education. From these, a sample of 6 programs was taken for the revision of the curricula or study plans to identify the existence of EE. On the other hand, the information was corroborated through surveys in a sample of two university programs through the consultation of their students. This survey allowed us to identify training aspects in EE, inside and outside the curriculum. The results will serve as input for the improvement of these environmental engineering programs, not only in Colombia but in several places where this type of engineering is offered.

\section{Environmental Education in Environmental Engineering in Colombia}

In a society defined as a "society of knowledge", education evolves with greater speed. In the decade between the 1990s and 2000s, virtual education was not conceived, but 10 years later, it began to grow, generating changes and new paradigms. Entirely virtual universities arose in this context, leading education to evolve along with social and technological evolution [29]. The same happens in environmental terms, i.e., needs are increasing and the requirements at the government level are aligned according to the terms of reference established by the UN. In this sense, the greatest current challenge is the SDGs; however, countries like Colombia do not recognise these needs and, therefore, ESD is not well known, even when universities or higher education institutions (HEIs) are considered major contributors in promoting environmental sustainability [30]. Latin America, in general, seems to have the same drawback, and most references to ESD are given in primary schools and by nongovernmental institutions or foundations [30]. However, there are a few approaches to ESD by universities [13]. 
Universities in Colombia, as in other places, add value to the regions where they are located because, in addition to generating a diaspora of cognitive growth, they contribute to the creation and improvement of links between companies and economic, environmental, social, and cultural managers. Therefore, it could be said that education, in general terms, seeks to give people the tools of validated knowledge to solve contemporary problems and to be dynamic, adaptive, and capable of leading us to generate new knowledge by promoting changes and improvements in society. In this sense, EE and ESD arise as a result of the historical context and the uncertainty of a future in social terms due to the existence of human species, which we have faced since the end of the 20th century. Universities are being forced to face these challenges by application of these two currents: EE and ESD.

Universities play a relevant role in solving the current socioenvironmental crisis; the environment requires preparing its members to face the challenges that come with it: climate change, the degradation of natural resources, territorial conflicts arising from the expansion of the agricultural frontier, the generation of solid waste, and the contamination of water sources, among many other issues [31]. Teaching and research must be the main agents of change based on responses to the problems and challenges of society, dealing with issues related to the environment in any type of educational context, such as responsible consumption, conservation of biodiversity, or the economy, among others. This leads to the promotion and strengthening of environmental education processes [31,32].

In line with these needs, some universities that are committed to the environmental issue have sought to create participation programs, implement environmental management systems such as EMAS or ISO 14001, as well as create environmental academic lines and undergraduate and postgraduate programs, among many other things [33]. Some bachelor and engineering degrees that are dedicated to the environment are gaining more and more spaces in universities; one of the most common ones in Latin America is environmental engineering, which is rich in curricular uncertainties that must be investigated in order to strengthen graduate students so that they can face the changing environment on a planet increasingly in need of solutions to its environmental problems [34].

In contrast, it has been noticed that higher education is not playing this important role, especially in Latin America, since the effect on students and graduates, in proenvironmental attitudes and solutions to environmental problems, is minimal [35]. The universities, therefore, must increase their efforts so that the environmental permeates all its spheres of action: teaching, research, operations, and social responsibility [19,36], acting in accordance with global guidelines on environmental education such as the Talloires Declaration of Bergen, Turin, the University Charter for sustainable development, and many others [36,37], as well as determining whether ESD is the correct way to achieve the SDGs [38].

Environmental engineering exists in almost all countries, but it is seen in different ways; in most developed countries, it is part of the formation of civil engineering programs, focusing mainly on basic sanitation $[39,40]$. However, it has been expanded to cover topics such as air, soil, water, and independent civil engineering programs called environmental engineering. However, the needs and skills of the environmental engineer increasingly require changes that involve interdisciplinary and global contexts [41]. This adaptation is evident in countries like Canada, the United States, and Japan, but in regions such as Latin America, it seems to be stagnant in sanitation issues; therefore, it lacks an identity as a profession or discipline [42,43].

Environmental engineering is growing and spreading rapidly among universities in developing countries [38], but since this profession is not too involved in global changes and context needs, it is not responding to the real need of the environment.

Environmental education is a very widespread term in daily life in Colombia, but little is done about it in several universities in Latin America, where there has been little research and what has already been done is conceptual and theoretical [44]. Most of the research is dedicated to evidencing the need to implement EE, demonstrating through questionnaires that there is environmental damage, and focusing on the attitude and disposition of the students [4]. 
One of the weaknesses of EE is that it has devoted itself to theory and explanation through short masterclasses, with little time and sporadically, which does not create a bridge between theory and practice; this delimits the behavior that finally has a positive effect on the environment $[44,45]$.

At this point, it is important to conclude that, in Colombia, ESD is not formally seen or used by this name, but it is embedded in EE. In other words, within the actions that Colombia classifies as EE, many are actions and forms of ESD [46,47]. That is why in the development of this study, it is important to keep in mind that when EE is mentioned, it is not an ancient concept anchored solely to the generation of consciousness and a certain romantic sense. On the contrary, it is a concept that has evolved [48-51], where technical concepts are the support for decision-making in order to generate a change in consumer attitudes and responsibility towards the environment. It is usual to see EE generating spaces for educational transformation, with support from biology, physics, and economics [1,48,50,52], far from classic EE. This is not intended to erase some characteristics or criticisms of EE, such as the political inclination or the mandatory need to have physical contact with ecosystems in order to protect them, marked in "if I know it, I protect it", among other criticisms [53,54]. In turn, its ESD counterpart also has criticisms, such as anthropocentrism [55,56].

\section{Methodology}

\subsection{Review of the Environmental Engineering Curriculum}

It was taken as a premise that the study plan is the materialization of the curriculum. It includes what is considered as valid knowledge and sets out the criteria of relevance and validity for the discipline, in addition to reflecting the interests of higher education institution [57]. It is important to highlight that Colombia has certain peculiarities, which give a different context to this research, since curricular reviews, updates of study plans, and the inclusion of innovative topics are unusual due to the lack of teachers or experts dedicated to these topics, especially in engineering programs $[57,58]$. In this sense, in general, it is taken as a basis that the curriculum in engineering programs in Colombia is a central tool, establishing itself as a guide in the structure and training of graduates [59]. Engineering degrees in Colombia usually last 5 years, distributed in 10 academic semesters.

For the methodological development of the study plan, public information was taken from a sample of $6(n=6)$ environmental engineering programs in Colombia, selecting universities that are recognized with high-quality accreditation by the Ministry of National Education. The academic courses or subjects were reviewed, as well as the existence of environmental education in the objectives proposed by each university for environmental engineering. Once the information was reviewed, it was corroborated with the students of these programs through surveys, verifying that EE is included in their training. The information provided by the students was compared with the curriculum to finally carry out a discussion about the training of these engineers in environmental education. Figure 1 shows the EE verification process in the training of environmental engineers in Colombia.

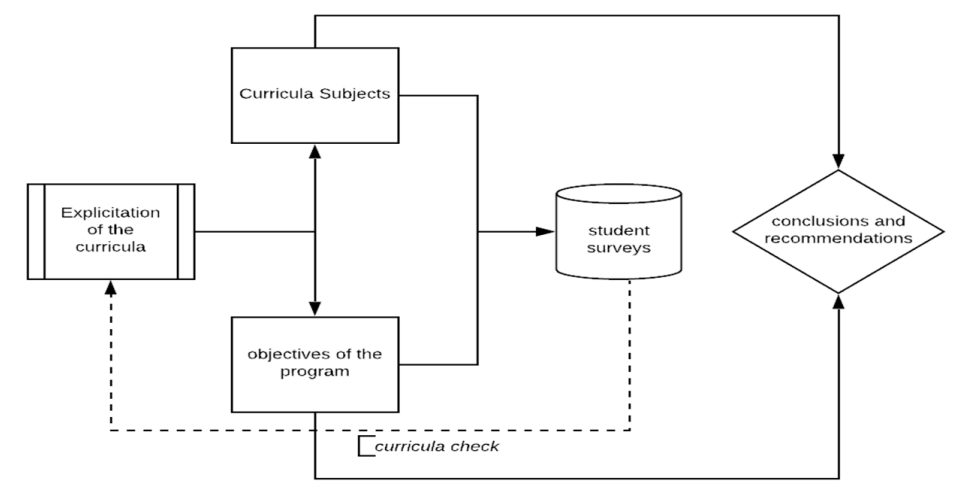

Figure 1. Verification methodology of environmental education (EE) in environmental engineering in Colombia. 


\subsection{Collection of Curricular Data}

A search was carried out for terms such as environmental education and education for sustainable development within the study plans, that is, to identify whether the terms were explicit within the study plan or there were courses with this name. Likewise, the public information on the web pages of the engineering programs was searched, and it was verified that there are some references to $E E$ and ESD in the syllabus or contents of the environmental engineering programs.

Environmental engineering is currently offered in 46 universities in Colombia, but only 14 are accredited. Higher education institutions that hold high-quality accreditation indicate the quality in academic processes. To opt for such a title is voluntary and governed by law, it ensures that both universities and programs meet national and international standards [59]. From the total amount of accredited universities $(n=11)$ for the year 2019, a random sample of $6(n=6)$ universities was taken. This sample corresponds to $42 \%$ of the total, namely, Santo Tomás University, Libre University, El Bosque University, Boyacá University, Pedagogical and Technological University of Colombia, and La Salle University.

\subsection{Surveys}

To corroborate the analysis in the curricula or study plans, a survey was conducted in two universities of the general sample. From the Universidad del Bosque, 95 students were interviewed ( $n=95)$, with 155 students from the Universidad Santo Tomás $(n=155)$. All of them were active students of environmental engineering programs. The rest of the universities either refused to participate or there was no official response. The questionnaire included 16 questions that are shown in Table 1. A confidence interval, according to Equation (1), and a standard normal distribution were used [60].

$$
p-e<\pi<p+e
$$

Table 1. Questionnaire for environmental engineering students around EE.

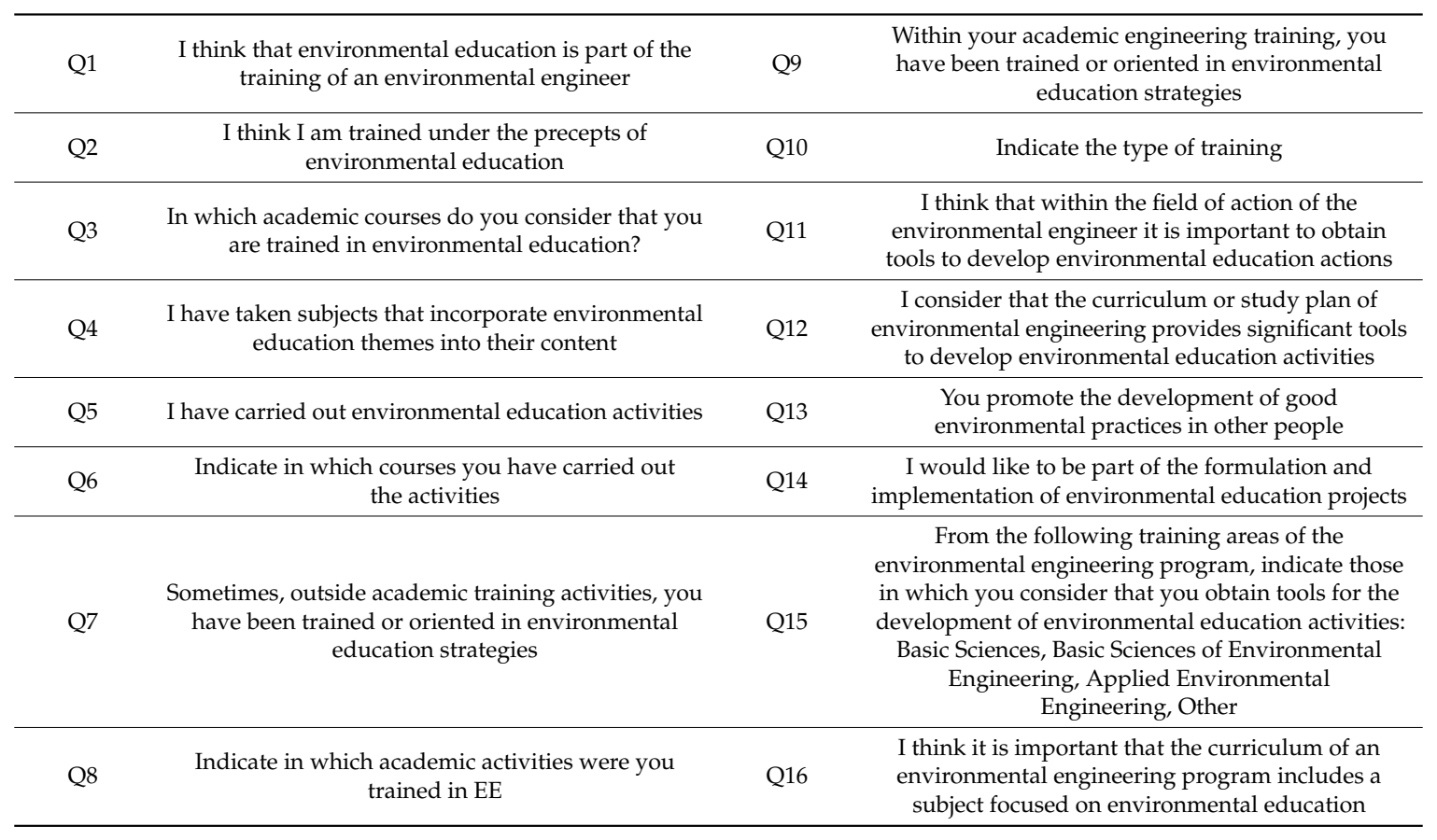

This formula allows the estimation of the proportion of students who meet a certain condition according to the survey questions. The value $\pi$ represents the population proportion (what we want to estimate) and it is estimated by $p=\frac{x}{n}$, which corresponds to the sample proportion, where $x$ is the 
number of successes in the sample and $n$ the sample size. The value $e$ represents the margin of error of the estimation, which is defined as $e=Z \sqrt{\frac{p q}{n}}$; the value of $Z$ allows us to find the critical point for a confidence level 1- $\alpha$.

The sample included $85.2 \%$ of students with ages between 18 and 22; $8.4 \%$ were between 23 and 29 and $6.4 \%$ were between 16 and 17 years old. On the other hand, $65.6 \%$ of the students were female and $34.4 \%$ male. In addition, $72 \%$ were studying from the third to the seventh semesters, $16 \%$ in the eighth and ninth semesters, and $12 \%$ were studying in the first and second semesters. It is important to take into account that higher education in Colombia is divided into semesters. In total, $100 \%$ of the surveyed students studied environmental engineering; from these, 38\% studied at El Bosque University while $62 \%$ did so at the Santo Tomás University.

\section{Results}

\subsection{Analysis of the Curricula}

All courses from the curricula and from all semesters were analyzed; this analysis indicates which ones directly or indirectly address the principles of EE. In this sense, some courses were found where it is essential to use EE or ESD tools. For example, the waste management course, which is common in all environmental engineering programs. In this course, modules are connected through environmental education, i.e., with topics such as source reduction, sorting, reuse, recycling, and many other tools that seek to minimize the final disposal of solid waste. Other courses include EE or ESD tangentially through the teaching of ISO 14001 standards, which is also common in all the reviewed study plans. Some courses like environmental policy, ecology, and environmental impact are in this same line, but they only represent, on average, $5 \%$ of the courses in the study plans, with the environmental engineering program of the Pedagogical and Technological University of Colombia having the most representativeness, namely, $8 \%$ of subjects had courses dedicated to EE.

Only the Santo Tomás University offers an elective course dedicated exclusively to ESD. In contrast, particularities were found in the study plans that include courses exclusively dedicated to EE and its promotion. It is important to highlight that it is not very representative compared to the total; in this case, the Pedagogical and Technological University of Colombia also stands out with $4 \%$.

Table 2 shows a summary of the quantitative analysis of academic spaces that directly or indirectly deal with EE structure. It is important to highlight that there is evidence of a disarticulation in the training process focused on promoting EE, but the homogeneity is remarkable among the programs of all the universities in the sample, which focus their subjects on attitudes typical of EE, especially the case of solid waste management.

Table 2. Analysis of the academic load designated to EE in the environmental engineering programs of the sample.

\begin{tabular}{cccccc}
\hline $\begin{array}{c}\text { University Offering } \\
\text { Environmental Engineering }\end{array}$ & $\begin{array}{c}\text { Academic Spaces with a } \\
\text { Focus on EE or ESD }\end{array}$ & $\begin{array}{c}\text { Academic Credits } \\
\text { Focus on EE or ESD }\end{array}$ & $\begin{array}{c}\text { \% of Courses Focus } \\
\text { on EE or ESD }\end{array}$ & $\begin{array}{c}\text { Exclusive } \\
\text { Courses for EE }\end{array}$ & $\begin{array}{c}\text { Exclusive Courses } \\
\text { for ESD }\end{array}$ \\
\hline 1 & Universidad Santo Tomás & 3 & 12 & $5 \%$ & 0 \\
\hline 2 & Universidad El Bosque & 5 & 15 & $6 \%$ & 1 \\
\hline 3 & $\begin{array}{c}\text { Universidad Pedagógica } \\
\text { y Tecnológica de } \\
\text { Colombia }\end{array}$ & 4 & 12 & $8 \%$ & 2 \\
\hline 4 & Universidad Libre & 2 & 6 & $3 \%$ & 0 \\
\hline 5 & Universidad de Boyacá & 3 & 12 & $5 \%$ & 0 \\
\hline 6 & Universidad de la Salle & 3 & 12 & $5 \%$ & 1 \\
\hline
\end{tabular}

\subsection{Surveys}

Most of the surveyed students considered that environmental education is part of their academic training. In addition, 38\% of the students of the El Bosque University and $61.2 \%$ from Santo Tomás University agreed that they had been trained in EE. In the questions related to the content of the subjects 
that are associated with EE, 56.4\% of the students of the Santo Tomás University answered that their course content incorporated topics of EE in contrast to 33.6\% of the students of El Bosque University.

In the case of students in Semesters 6 to 10, it was observed that 20\% of the students stated that environmental legislation incorporates EE topics, followed by environmental solutions (14.8\%). In Environmental Management and Environmental Impact courses, $10.4 \%$ of students answered the same. In most of the subjects of the applied engineering area, EE topics were incorporated, but in different percentages.

Subjects in the area of basic engineering, which correspond to Semesters 4 to 6, incorporate EE topics: $30.8 \%$ of the students stated that the introduction to environmental engineering incorporates EE topics, followed by topics of ecology and microbiology with $18.8 \%$ of students each. In the subject of environmental economics, $11.6 \%$ of the students affirmed it. In the area of basic sciences, $6.4 \%$ of the students stated that in biology, EE topics were incorporated; in chemistry, $0.8 \%$ of the students stated that EE topics were incorporated.

In general, it is found that $94 \%$ of the students affirmed that in the applied engineering area, EE themes were used; $47.6 \%$ in basic engineering, $7.2 \%$ in basic sciences, $2 \%$ in electives, and $2 \%$ in all subjects. In addition, $70 \%$ of the students carried out environmental education activities. The activities in which the surveyed students, who carried out EE activities within the subjects, had participated are summarized in Table 3.

Table 3. EE activities that students do in environmental engineering subjects.

\begin{tabular}{cc}
\hline Activities & Percentage \\
\hline Community work & $56 \%$ \\
\hline Personal activities & $29 \%$ \\
\hline Research projects & $6 \%$ \\
\hline Field trips & $8 \%$ \\
\hline
\end{tabular}

Among the community work activities that the students develop are waste collection, tree planting, cleaner production, talks in schools, colleges, and industries, application of the 3Rs (reduce, reuse, and recycle), waste management, reforestation, river cleaning, biogas generator, creation of tourist trails, and green markets. Among the personal activities are training, courses, forums, seminars, energy- and water-saving, construction of environmental education booklets, waste separation, calculating the carbon footprint of homes, environmental awareness, measuring water quality, debates, readings, and the study of wetlands. Likewise, research projects in which the students participated were environmental management plans and cleaner production at home.

In total, $52 \%$ of the surveyed students received training in EE strategies. Of these, $100 \%$ participated in extracurricular activities (application of SGDs, talks, conferences, forums, good practices, and workshops) and personal activities: $92.8 \%$ in subjects and $8.4 \%$ in complementary activities of the degree (3Rs management, field trips, resource optimization, risk analysis, investigation, the validity of environmental processes, and research). It is important to highlight this percentage value as it is an indicator of the tastes and needs of the students.

In addition, $98 \%$ of the surveyed students stated that it is important to obtain tools for the development of actions in EE, and 85\% affirmed that the curriculum provides significant tools for the development of EE activities. Of the surveyed students, $90 \%$ would encourage other people to develop good environmental practices, $94 \%$ of the respondents would like to be part of the formulation and implementation of EE projects, $69 \%$ of those surveyed considered that they obtained tools for the development of EE activities in applied engineering subjects, $29 \%$ in basic engineering science subjects, and only $2 \%$ in basic science subjects.

Figure 2 describes that $95.2 \%$ of the surveyed students affirmed that EE must be part of the study plan; 59.6\% from Santo Tomás University and 35.6\% from El Bosque University. As random and 
independent samples were taken in each of the two universities studied, it can be affirmed with $95 \%$ confidence that between $89 \%$ and $94 \%$ of the students from El Bosque University have indicated the importance of a subject focusing on EE within the study plan, while in Santo Tomás University, this rate is between $93 \%$ and $99 \%$.

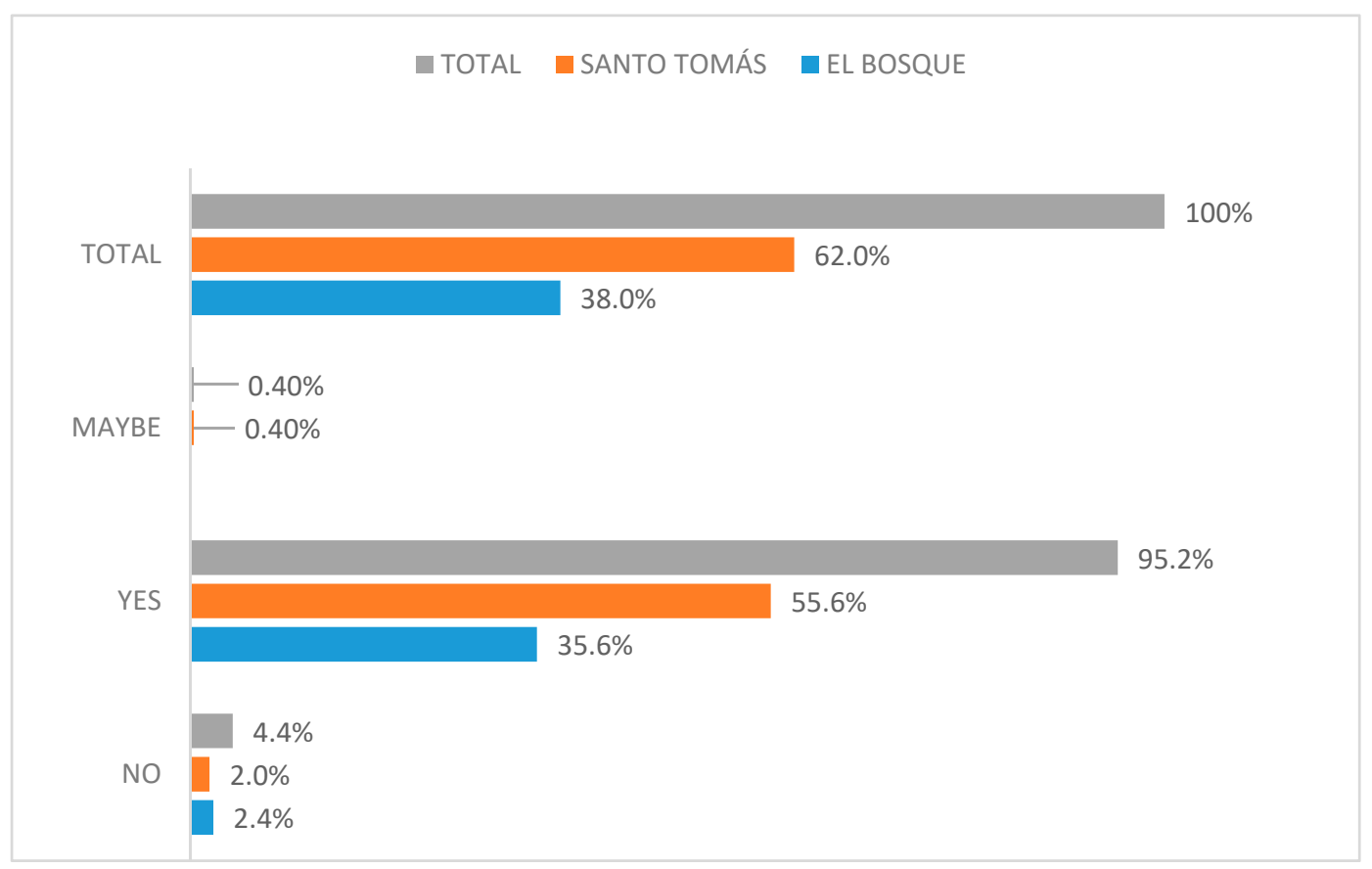

Figure 2. Environmental engineering students who stated the need to have the environmental education (EE) subject within the curriculum.

On the other hand, the students indicated that environmental engineering programs lack tools that help them prepare and train in EE; $66 \%$ of the surveyed students affirmed that the program they were studying lacked tools to train them in EE, $62 \%$ from Santo Tomás University and 38\% from El Bosque University.

\section{Discussion}

In all the cases reviewed in the sample, the study plan remains dedicated, in greater proportion, to issues related to basic sanitation, which responds to the country's needs. This may indicate a delay in the process of updating the engineering curriculum. Therefore, the environmental engineering curricula in Colombia must change to adapt to the future characteristics of the country, where environmental engineering is not focused anymore on sanitation aspects, without neglecting it. More holistic aspects, such as environmental sustainability, must be addressed [53]. Colombia is among the Latin American countries with $97 \%$ potable water and sanitation coverage in urban areas, and it is expected to have $100 \%$ rural and urban coverage for both sectors by 2030 [61]. Therefore, environmental engineering must be directed towards an increasingly developed country, with more marked needs towards the protection of Colombia's natural characteristics, especially biodiversity and water supply, since it ranks 17 th in biodiversity and 3rd in water reserves in the world. Moreover, it owns $50 \%$ of the moors that the planet has, in addition to $53 \%$ of the territory of natural forests, among many other environmental riches.

It is important to highlight that although it is assumed that university students of environmental or ecological degrees have strong training or conviction towards environmental education, this is not common; this is corroborated by the surveys carried out [28]. In addition, a lack of teacher training in universities is inferred, since most of the teachers have been trained under the same scheme as their students, that is, with few notions of environmental education [62], which in turn, demonstrates 
the lack of support for higher education on environmental and sustainability issues. This makes it difficult for these places to become examples to be followed or used as a platform to achieve sustainable development goals [63].

Environmental engineering, like any other profession, must continually adapt to the challenges posed by the environment, especially this program that is born in modern times, where each decade represents unprecedented leaps in knowledge. This implies that it must evolve in line with the needs of the environment, but it seems that the processes of contamination and degradation of natural resources are overcoming [63]. In this situation, environmental engineers must not only respond from their technical base, which is their support and backbone, but from the ability to prevent pollution by promoting attitudes that generate awareness with the environment, seeking to conserve natural resources and its sustainability, generating synergies between the solution to a contamination process through techniques and mitigation in magnitude from environmental education. This seems to be clear to the students, but the curriculum has not responded adequately since most of the training in EE is done by self-management, that is, by the student's search and not because the university provides the tools within the curriculum to achieve it. There is also a notorious disparity between universities, both those surveyed and those analyzed; some have a greater inclination towards EE without this being representative, while others have even less representation of EE in the curricula.

Therefore, the need arises to incorporate EE to a greater extent in environmental engineering study plans, making them more consistent with environmental problems. This need is reflected in the results of the surveys applied to environmental engineering students; they want to become engineers who prevent and not only mitigate environmental impacts. This knowledge of prevention is achieved with appropriate and proven tools, such as the case of EE. In addition to the fact that it is in Colombia, incorporating ESD also serves as a way to achieve sustainable development. It was clearly evident that the curricula of this profession do not respond to the needs and demands of their own students; therefore, it could be said that they are not fully relevant. It is necessary to clarify that this research is not intended to affirm that this engineering curriculum is not responding in its entirety to the needs of the environment or that it is not entirely pertinent, but, rather, it must incorporate environmental education as a transversal tool to all its learning processes, assimilating the example given above of the solid waste subject, which is taught in the same way in all universities.

In all universities, it is common to see the core or subjects of the institution as those that give the distinctive feature to the student who graduates from the university, as well as subjects and content that urge the student to be trained in vital aspects such as ethics and other factors inherent to their discipline that promote interdisciplinarity [64]. The same can occur with environmental education or with sustainable development by incorporating environmental education or sustainable development in the syllabus [65]. This would not only respond to the needs of the students, but each subject would be aligned with policies such as the 2030 agenda and SDGs [66].

Another alternative is the inclusion, within the curriculum, of a subject such as environmental education or education for sustainable development. In this case, there is evidence of the success of this proposal in civil and environmental engineering in the University of Colorado, USA, where a sustainability subject that led students to have a broader environmental perspective was incorporated. This subject affected the students' concept of its importance in civil and environmental engineering [67].

\section{Conclusions}

Environmental engineering curricula in Colombia are not appropriate for the future needs of the environment nor for the current demands of the students, especially in environmental education. While students and the country goals indicate the need for an environmental engineer that knows and manages strategies in this regard, the curricula in Colombia incorporated only $5 \%$ (on average) of these aspects. Therefore, the way forward is for environmental engineering to be updated so that its curriculum responds not only to student needs but also to global environmental challenges and aligns with initiatives such as the sustainable development goals proposed by the UN. In this sense, it was 
possible to identify that students see the need for a course focused on environmental education in both analyzed universities. Between $89 \%$ and $94 \%$ of students from El Bosque University and between $93 \%$ and $99 \%$ of students from Santo Tomás University determined that there is a need for this course.

To meet these needs, universities have to train, learn, and know about environmental education. Students have been using extracurricular strategies because they do not find another solution within the environmental engineering curriculum. Therefore, it was observed that $52 \%$ of students participating in the survey received training in EE strategies, and all of them participated in extracurricular activities, highlighting the self-management activities of $28.06 \%$ of those surveyed. Among the activities that were most frequently used by students are the 3Rs (reduce, reuse, and recycle) and readings, among others.

With the survey, it was possible to identify valuable contributions of the curricula and that many subject areas trained their students in proenvironmental attitudes within the framework of environmental education, especially the subjects that correspond to higher levels, that is, the area of applied engineering. However, it was observed that in the subjects of the area of basic sciences (biology, mathematics, calculus, physics, and chemistry), it is necessary to implement content related to environmental education.

It is important to continue research on environmental education in environmental engineering and to streamline the curricular update to make it relevant for Colombia to be a contributor to the sustainable development process in which it is framed. The constant evaluation and curricular self-evaluation of this engineering program will generate people with greater knowledge and holistic views that promote adequate management of natural resources. In these processes, universities must observe the progress that the country is making in aspects that are typically addressed by environmental engineers, such as water treatment and basic sanitation, and explore aspects such as sustainable infrastructure, air pollution, and technological development with the support of environmental education.

Author Contributions: The contribution of all authors of this paper was very similar, as all of them have collaborated in the elaboration, validation, reviewing edition, and the location of the used resources. Finally, A.Q.-D. and A.H.E. are responsible for the funding acquisition. All authors have read and agreed to the published version of the manuscript.

Funding: This research received no external funding.

Conflicts of Interest: The authors declare no conflict of interest.

\section{References}

1. Sosa, S.B.; Isaac-Márquez, R.; Eastmond, A.; Ayala, M.E.; Arteaga, M.A. Educación superior y cultura ambiental en el sureste de México. Univ. Cienc. 2010, 26, 33-49.

2. Vidiella, A.Z. Enfoque Globalizador y Pensamiento Complejo: Una Respuesta Para la Comprensión e Intervención en la Realidad; Graó: Barcelona, Spain, 1999; Volume 1, ISBN 84-7827-125-2.

3. De Andrade Guerra, J.B.S.O.; Gárcia, J.; Lima, M.D.A.; Barbosa, S.B.; Heerdt, M.L.; Berchin, I.I. A proposal of a Balanced Scorecard for an environmental education program at universities. J. Clean. Prod. 2018, 172, 1674-1690. [CrossRef]

4. Gaudiano, E.G.; Valdez, M.R.E. Enfoques y sujetos en los estudios sobre representaciones sociales de medio ambiente en tres países de Iberoamérica. CPU-E Revista Investig. Educ. 2012. [CrossRef]

5. Tejedor, G.; Segalàs, J.; Rosas-Casals, M.; Rosas, M. Transdisciplinarity in higher education for sustainability: How discourses are approached in engineering education. J. Clean. Prod. 2018, 175, 29-37. [CrossRef]

6. Guide: University of the West of England. Education for Sustainable Development: Guidance for UK Higher Education Providers. J. Educ. Sustain. Dev. 2015, 9, 117. [CrossRef]

7. Holst, J.; Brock, A.; Singer-Brodowski, M.; de Haan, G. Monitoring Progress of Change: Implementation of Education for Sustainable Development (ESD) within Documents of the German Education System. Sustainability 2020, 12, 4306. [CrossRef]

8. Brundtland, G.H. Informe de la Comisión Mundial sobre Medio Ambiente y el Desarrollo: Nuestro Futuro común; ONU: New York, NY, USA, 1987; ISBN 9780969453802. 
9. Waas, T.; Hugé, J.; Block, T.; Wright, T.; Benitez-Capistros, F.; Verbruggen, A. Sustainability Assessment and Indicators: Tools in a Decision-Making Strategy for Sustainable Development. Sustainability 2014, 6, 5512-5534. [CrossRef]

10. Biasi, P.; Ferrini, S.; Borghesi, S.; Rocchi, B.; di Matteo, M. Enriching the Italian Genuine Saving with water and soil depletion: National trends and regional differences. Ecol. Indic. 2019. [CrossRef]

11. Becker, G. Climate Change Education for Sustainable Development in Urban Educational Landscapes and Learning Cities. Experiences Perspectives from Osnabrück BT-Lifelong Learning and Education in Healthy and Sustainable Cities; Azeiteiro, U.M., Akerman, M., Leal Filho, W., Setti, A.F.F., Brandli, L.L., Eds.; Springer International Publishing: Cham, Switzerland, 2018; pp. 439-469, ISBN 978-3-319-69474-0.

12. McKeown, R. Education for Sustainable Development Toolkit Version 2; Univesity of Tennesse: Knoxville, TN, USA, 2002, ISBN 9789158641310.

13. UNESCO. Shaping the Future We Want-UN Decade of Education for Sustainable Development (Final Report) Sustainable Development Knowledge Platform; UNESCO: Paris, French, 2014; ISBN 978-92-3-100053-9.

14. UNESCO. Intergovernmental Conference on Environmental Education Organized (Tbilisi, USSR, 14-26 October 1977). Final Report; UNESCO: Paris, French, 1978.

15. Kibbe, A.; Bogner, F.X.; Kaiser, F.G. Exploitative vs. appreciative use of nature-Two interpretations of utilization and their relevance for environmental education. Stud. Educ. Eval. 2014, 41, 106-112. [CrossRef]

16. Frantz, C.M.; Mayer, F.S. The importance of connection to nature in assessing environmental education programs. Stud. Educ. Eval. 2014, 41, 85-89. [CrossRef]

17. Carleton-Hug, A.; Hug, J.W. Challenges and opportunities for evaluating environmental education programs. Eval. Program Plan. 2010, 33, 159-164. [CrossRef]

18. Ágnes, Z.; Szerényi, Z.M.; Széchy, A.; Kocsis, T. Greening due to environmental education? Environmental knowledge, attitudes, consumer behavior and everyday pro-environmental activities of Hungarian high school and university students. J. Clean. Prod. 2013, 48, 126-138. [CrossRef]

19. Lozano, R. Incorporation and institutionalization of SD into universities: Breaking through barriers to change. J. Clean. Prod. 2006, 14, 787-796. [CrossRef]

20. Ariza, C.P.; Rueda Toncel, L.Á. La educación ambiental: Una mirada desde el contexto universitario. Boletín Redipe 2016, 5, 116-124.

21. Ezquerra, A.A. La Universidad en la encrucijada. Magriberia 2011, 5, 25-44.

22. Maroto, J.P. La medicina y la ingeniería en la salud ambiental, Madrid: Instituto de España Real Academia Nacional de Medicina. Rev. Obras Públicas 1969, 3046, 87-113.

23. Durán, G.G. Surgimiento y evolución de la Ingeniería Ambiental en Colombia. Rev. Ing. 2007, $122-130$. [CrossRef]

24. Clark, S.G.; Rutherford, M.B.; Auer, M.R.; Cherney, D.N.; Wallace, R.L.; Mattson, D.J.; Clark, D.A.; Foote, L.; Krogman, N.; Wilshusen, P.; et al. College and University Environmental Programs as a Policy Problem (Part 1): Integrating Knowledge, Education, and Action for a Better World? Environ. Manag. 2011, 47, 701-715. [CrossRef]

25. Sterbuleac, D.; Toma, O. Environmental education through a University Eco-Consortium. Appl. Environ. Educ. Commun. 2018, 19, 62-73. [CrossRef]

26. De la Harpe, B.; Thomas, I. Curriculum Change in Universities. J. Educ. Sustain. Dev. 2009, 3, 75-85. [CrossRef]

27. Sterbuleac, D.; Toma, O. The overlooked role of academic environmental organizations in addressing environmental education issues. Appl. Environ. Educ. Commun. 2018, 18, 91-94. [CrossRef]

28. Liu, S.-C.; Lin, H.-S. Exploring Undergraduate Students' Mental Models of the Environment: Are They Related to Environmental Affect and Behavior? J. Environ. Educ. 2014, 46, 23-40. [CrossRef]

29. Trillo, M. De la educación a distancia a la educación virtual. Te Et. 2009, 4, 303. [CrossRef]

30. De Amorim Soares, M.L.; Petarnella, L. Schooling for Sustainable Development: Autonomy, Citizenship and Social Justice in South America. In Schooling for Sustainable Development in South America; Springer: Dordrecht, The Netherlands, 2011; pp. 3-18.

31. Niño, A.C.M.; Romero, J.F.H. La formación ambiental en la educación superior:una revisión necesaria. Luna Azul 2014, 186-206. [CrossRef]

32. Quiva, D.; Vera, L. Environmental Education as a Tool to Promote Sustainable Development. Telos 2010, 12, 378-394. 
33. Leon-Fernandez, Y.; Gomera, A.; Antúnez, M.; Martínez-Escrich, B.; Villamandos, F.; Vaquero, M. Enhancing environmental management in universities through participation: The case of the University of Córdoba. J. Clean. Prod. 2018, 172, 4328-4337. [CrossRef]

34. Mitsch, W.J. What is ecological engineering? Ecol. Eng. 2012, 45, 5-12. [CrossRef]

35. Meyer, A. Does education increase pro-environmental behavior? Evidence from Europe. Ecol. Econ. 2015, 116, 108-121. [CrossRef]

36. Wright, T.S.A. Definitions and frameworks for environmental sustainability in higher education. Int. J. Sustain. High. Educ. 2002, 15, 105-120.

37. Tilbury, D. Higher Education for Sustainability: A Global Overview of Commitment and Progress. In Higher Education in the World 4. Higher Education's Commitment to Sustainability: From Understanding to Action; Global University Network for Innovation (GUNI), Ed.; Palgrave Macmillan: Barcelona, Spain, 2012; pp. 18-28.

38. Karatzoglou, B. An in-depth literature review of the evolving roles and contributions of universities to Education for Sustainable Development. J. Clean. Prod. 2013, 49, 44-53. [CrossRef]

39. Jahanbakhsh, A.; Pournik, M.; Nakhaee, A.; Sadighi, A.; Azadpour, M.; Emad, M. A Comparative Study of Engineering Education in Iran and USA: An Attitude Survey of Iranian Students Abroad. 2009, pp. 1-8. Available online: http://www.isee.ir/FileForDownload/files/76.pdf (accessed on 3 September 2020).

40. Ghaffari, S.; Talebbeydokhti, N. Status of Environmental Engineering Education in Various Countries in Comparison with the Situation in Iran. Procedia Soc. Behav. Sci. 2013, 102, 591-600. [CrossRef]

41. Tansel, B. Changing the Status Quo in Environmental Engineering Education in Response to Emerging Markets. J. Prof. Issues Eng. Educ. Pract. 2008, 134, 197-202. [CrossRef]

42. Rodríguez-Roda, I.; Castells, F.; Flotats, X.; Lema, J.; Tejero, I. Environmental engineering education in Spain. Water Sci. Technol. 2004, 49, 101-108. [CrossRef] [PubMed]

43. Nguyen, D.Q.; Pudlowski, Z.J. An Overview of Environmental Engineering Education in The Past Decade: A Global Perspective. In Proceedings of the 2nd WIETE Annual Conference on Engineering and Technology Education, Pattaya, Thailand, 25-28 January 2011; pp. 25-28.

44. Arboleda, I.F.M.; Páramo, P. La investigación en educación ambiental en América Latina: Un análisis bibliométrico. Rev. Colomb. Educ. 2014, 1, 55-72. [CrossRef]

45. Chawla, L.; Derr, V. The development of conservation behaviors in childhood and youth. Oxford Handb. Environ. Conserv. Psychol. 2012. [CrossRef]

46. López, L.M.R.; Londoño, J.V.E.; de Jesús Arango Ruiz, A.; Molina-Benítez, J.-A.; Parodi, T.V.; Montaña, D.F.V. Educación para el desarrollo sostenible: Acercamientos desde una perspectiva colombiana. Prod. Limpia 2018, 13, 133-149. [CrossRef]

47. Fernando, G.S.H.; Eugenia, V.M.; Mauricio, A.C.P. Estudios Sobre Medio Ambiente y Sostenibilidad: Una Mirada Desde Colombia; Ediciones USTA: Bogotá, Colombia, 2018, ISBN 978-958-5471-12-2.

48. Kopnina, H. Neoliberalism, pluralism and environmental education: The call for radical re-orientation. Environ. Dev. 2015, 15, 120-130. [CrossRef]

49. Liu, S.-C. Environmental Education through Documentaries: Assessing Learning Outcomes of a General Environmental Studies Course. Eurasia J. Math. Sci. Technol. Educ. 2018, 14, 1371-1381. [CrossRef]

50. Ardoin, N.M.; Bowers, A.W.; Gaillard, E. Environmental education outcomes for conservation: A systematic review. Boil. Conserv. 2020, 241, 108224. [CrossRef]

51. Freidenfelds, D.; Kalnins, S.N.; Gusca, J. What does environmentally sustainable higher education institution mean? Energy Procedia 2018, 147, 42-47. [CrossRef]

52. Semerjian, L.; El-Fadel, M.; Zurayk, R.; Nuwayhid, I. Interdisciplinary Approach to Environmental Education. J. Prof. Issues Eng. Educ. Pract. 2004, 130, 173-181. [CrossRef]

53. Castellanos, P.M.A.; Dios, A.Q.; Ortegon, A.C. The lack of environmental education in the training of environmental engineers in Colombia. In Proceedings of the SEFI 47th Annual Conference: Varietas Delectat. Complexity Is the New Normality, Proceedings; European Society for Engineering Education (SEFI): Brussels, Belgium, 2020; pp. 70-82.

54. Ekpiken, W.E.; Ukpabio, G.U. Youth Empowerment in Higher Education for Sustainable Development of Developing Communities in Cross River State, Nigeria. Int. Educ. Stud. 2015, 8, 113-119. [CrossRef]

55. Bonnett, M. Sustainable development, environmental education, and the significance of being in place. Curric. J. 2013, 24, 250-271. [CrossRef] 
56. Kopnina, H. Education for sustainable development (ESD): Exploring anthropocentric-ecocentric values in children through vignettes. Stud. Educ. Eval. 2014, 41, 124-132. [CrossRef]

57. Balza-Franco, V. Formulación y diseño de un modelo de vigilancia tecnológica curricular en programas de ingeniería en Colombia. Rev. Educ. Super. 2016, 45, 55-77. [CrossRef]

58. Barriga, F.D. Aproximaciones metodológicas al diseño curricular: Hacia una propuesta integral. Tecnol. Comun. Educ. 1993, 21, 19-39.

59. CNA; CESU. Acuerdo 03 de 2014: Por el cual se aprueban los Lineamientos para la Acreditación Institucional. Cons. Nac. Acreditación Cons. Nac. Educ. Super. 2014, 32. Available online: https://www.cna.gov.co/1741/ articles-186370_acuerdo_03_2014.pdf (accessed on 3 September 2020).

60. Guan, Y. A generalized score confidence interval for a binomial proportion. J. Stat. Plan. Inference 2012, 142, 785-793. [CrossRef]

61. Rodríguez-Miranda, J.P.; García-Ubaque, C.A.; Garcia-Ubaque, J.C. Enfermedades transmitidas por el agua y saneamiento básico en Colombia. Rev. Salud Pública 2017, 18, 738. [CrossRef]

62. Hamalosmanoglua, M. The Place of Environmental Education in Science Education Curricula in Turkey. Procedia Soc. Behav. Sci. 2012, 46, 4839-4844. [CrossRef]

63. Shawe, R.; Horan, W.; Moles, R.; O'Regan, B. Mapping of sustainability policies and initiatives in higher education institutes. Environ. Sci. Policy 2019, 99, 80-88. [CrossRef]

64. Quelhas, O.L.; Lima, G.B.A.; Ludolf, N.V.E.; Meiriño, M.J.; Abreu, C.; Anholon, R.; Neto, J.V.; Rodrigues, L.S.G. Engineering education and the development of competencies for sustainability. Int. J. Sustain. High. Educ. 2019, 20, 614-629. [CrossRef]

65. Perpignan, C.; Baouch, Y.; Robin, V.; Eynard, B. Engineering education perspective for sustainable development: A maturity assessment of cross-disciplinary and advanced technical skills in eco-design. Procedia CIRP 2020, 90, 748-753. [CrossRef]

66. Mulder, K.; Segalas-Coral, J.; Ferrer-Balas, D. How to educate engineers for/in sustainable development. Int. J. Sustain. High. Educ. 2012, 13, 211-218. [CrossRef]

67. Bielefeldt, A.R. Incorporating a Sustainability Module into First-Year Courses for Civil and Environmental Engineering Students. J. Prof. Issues Eng. Educ. Pract. 2011, 137, 78-85. [CrossRef] 